\title{
The COVID-19 pandemic and the crisis of lockdowns in Nigeria: The household food security perspective
}

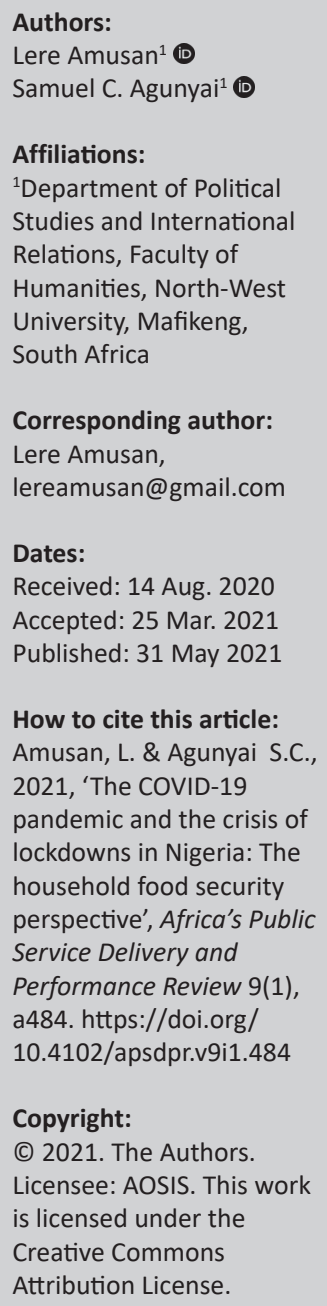

Background: This article argues that the lockdown policy of the Nigerian government, even though had proven to be effective in the control of the spread of the virus, adversely triggers household crises. These crises range from hunger, gender violence, shortage of food, low purchasing power and negative coping strategies. While intellectual resources have been remarkably outspoken about the effect of lockdown on Nigeria's economy, the implications of the lockdown for household food security crisis have drawn little or no academic attention.

Aim: Given this, the article examines the influence of the lockdown on households' hunger and coping mechanisms. It further examines the nexus between coronavirus disease 2019 (COVID-19) lockdown and households' low purchasing power.

Setting: This is with the view to advance adequate strategy for minimising the effects of lockdown on food (in)security in Nigeria.

Method: The article utilized a qualitative, descriptive research method. The article, is theoretical in nature, and drew its arguments from secondary sources, such as journals, books, newspapers, Internet sources, and official documents.

Results: The finding indicates that the lockdown stimulates not only households' hunger and negative coping habits but also low purchasing power.

Conclusion: The article concludes that equitable and transparent distribution of palliatives is a good strategy capable of addressing households' food (in)security crisis during Covid-19 lockdown in Nigeria.

Keywords: COVID-19; Nigeria; household food; human insecurity; lockdown; pandemic.

\section{Introduction}

The outbreak of coronavirus disease 2019 (COVID-19) in China and its spread to other countries including Nigeria has had a destructive impact on health, economy, infrastructure, human existence and food. But the evidence in recent studies and literature showed that more researchers, governments and major stakeholders have rather engaged in research that intends to bring a cure to the virus. Other studies have investigated the pandemic's impact on violence against children and women (Pereira et al. 2020; Peterman et al. 2020), health (Berger et al. 2020; United Nations 2020; World Health Organization [WHO] 2020), economy (Eichenbaum, Rebelo \& Trabandt 2020; Piguillem \& Shi 2020), education (United Nations 2020) and human safety (Lattouf 2020; National Domestic Violence Hotline 2020). This has created some gaps in addressing the effects of the epidemic on household food crises or insecurity. However, few studies have pointed out the implications of the novel virus for food insecurity (Guterres 2020; UNSCN 2020; World Food Programme [WFP] 2020). According to Food and Agriculture Organization (FAO 2020), the implications include hunger, sex-for-food, violence against women and girl children and negative coping habits, amongst others. These implications are a threat to humanity and global peaceful co-existence as the lockdown has inflicted devastating household hardships (food shortage, low disposable income, rape, sex-for-food and skipping of food, amongst others) in Nigeria (Hamza 2020; Laetitia 2020; Laura 2020; NCDC 2020; UNHCR 2020; United Nations 2020; WHO 2020). Besides, it is a threat to household security, especially the safety and adequate nourishment of children.

The coronavirus disease 2019 has implications for feeding of school children (Guterres 2020), especially those who may not have access to nutritious food at home. One of such implications is undernourishment or malnutrition of children. Malnutrition is caused by inadequate food utilisation and lack of access to nutritious food, which in turn causes food insecurity (United Nations 2020). This is so in that policies of stay-at-home, lockdown, self-isolation, quarantine and 
social distancing have not only restricted movement, but also adversely hampered food production, distribution, accessibility, affordability, utilisation and stability (Devereux 2018). For instance, with the total lockdown of communities, producers of agricultural food (farmers) and sellers (traders) find it very difficult to supply and trade in food. Consequently, this sends the price of food very high for householders, who at the same time have been locked out of their daily economic activities. The food chain in general was in total disarray. It equally affected the producers as their products, especially perishable foods such as vegetables, were rotten in farm, with financial implications on inputs incurred during planting, harvesting and packaging.

This had made many households resort to stringent coping strategies, such as skipping of food, reducing food consumption, engaging in low-nutrient food and excessive borrowing (debt) to buy food. Similarly, InterAction (2020) reports that public health emergencies, like COVID-19, Ebola Severe Acute Respiratory Syndrome (SARS), et cetera, have forced some households to adopt negative coping mechanisms, such as transactional sex, reduction of food consumption and engaging in debt to access food. Food insecurity caused by lockdowns or quarantine measures increases negative coping strategies, such as hazardous forms of child labour and child marriage (Doyle \& Aizer 2018; United Nations Coordinated Appeal 2020). Consequently, negative coping strategies triggered by low purchasing power to get adequate food as a result of an outbreak of a pandemic can lead to acute and chronic stress, which in turn provoke conflict, arguments and violence at the household level (Peterman et al. 2020).

This explains the rationale behind quarrels, abuses and domestic conflicts or violence between husband and wife in some households. The community is also not free of violence, triggered by households' food insecurity during the COVID-19 lockdown. In Nigeria, unlike other affected countries, the lockdown has not only subjected the already vulnerable households to hunger, but also created more tensions, violence and unfortunate killings of Nigerians by either hoodlums who are hungry and resort to attacking neighbouring households for food. Besides, security agencies, which are expected to act professionally and humanely in the handling of violators of the lockdowns order, because of the current hardship posed by the pandemic are engaged in firing, leading to loss of lives. Added to this is the increased susceptibility window to the hijacking of food (trailer load of rice, bread, eggs and other food edibles occasioned by the lockdown order without any palliative to the people, especially motor parks vehicle loaders [Agberos] who live on a daily income).

Given the above discussion, this study examines the COVID-19 pandemic, expanding crisis of lockdown and household food insecurity in Nigeria. A robust understanding of the implications of COVID-19 lockdown for food and human insecurity at household and community levels will guide the design and implementation of palliatives aimed at addressing problems of household food, intra-household violence and human insecurity during the lockdown in Nigeria. Thus, the awareness of the fact that the provision of palliatives, including nutritious food to people, especially during lockdowns, is a requisite to boosting people's immunity that can help fight the deadly virus, control household violence and reduce violent attacks on neighbouring households in the country.

\section{Conceptual review or clarification}

The initial collection of literature on this subject matter resulted in a countless search for studies, which have been largely focused on curative, clinical trials and economy-based research. At the time of conducting this research, not many researchers, including social sciences researchers, have probed the impact of COVID-19 on food, intra-family violence and human insecurity. Thus, while studies have investigated the impact of pandemics such as Ebola, SARS, etc., on food security, little is known about the impact of COVID-19 pandemic on household food security or insecurity except for journalistic position on the problem under consideration. Similarly, Pamela (2020) observed that at the beginning of the pandemic, little emphasis was placed on food security. This section, however, focused on the reviews of key concepts such as pandemics, COVID-19, lockdown and food security. It also reviews the connections between the key concepts, especially how the novel virus and its preventive measure (lockdown) provoked household food crises in Nigeria.

\section{Pandemics, lockdowns and household food (in)security or violence}

Pandemics are global or worldwide epidemics occurring over a wide area, spreading across international boundaries and affecting a large number of people (Heath 2011). It can also be seen as a simultaneous global transmission of diseases or viruses that cut across boundaries and continents. It is population immunity, virology or disease severity (Heath 2011). It is a disease outbreak that spreads across the world. Its rate of spread and infection is simultaneous and almost the same across countries of the world. From this definition, it is obvious that the COVID-19 disease is a pandemic, as it has all the conditions or features of a pandemic.

For instance, it has spread across continents, international boundaries and global space. It has the simultaneous transmission tendency, which makes it spread at the same time in different countries. The WHO declared COVID-19 as a pandemic when it was spreading rapidly across the world, affecting different countries (WHO 2020). Pandemics are diseases of very different aetiologies that exhibit a variety of epidemiologic features (Morens, Folkers \& Fauci 2009). A pandemic is a widespread outbreak of a deadly disease or virus that cuts across boundaries, race, religion and levels of education, which normally affects health, lives, countries, governments, means of livelihood of individuals, community, and generally the people. The foregoing view is well documented in Porta (2014), who sees it as an epidemic occurring over a very wide area, crossing international boundaries, and usually affecting a large number of people. Similarly, WHO (2010) sees pandemics as a disease that is 
easily identified by their geographical scale and reach rather than the severity of the illness. It is a virus that spreads through person by person, that is, the virus by itself has limited spreading ability, but spreads widely through person by person. This is similar to how Rothan and Byrareddy (2020) described its spread, in which several reports have suggested that person-to-person transmission is a likely route for spreading COVID-19 infection.

From the definitions above, COVID-19 is a disease that assumed a pandemic status on 11 March 2020 (WHO 2020). The pandemic since its outbreak in Wuhan, China, had severely threatened human existence. It is a virus that knows no border or person, nor does it discriminate based on nationality. It affects all humans, countries and economies - a confirmation of 'globalization and its discontents' (Stiglitz 2002). Narendra, Saurabh and Arun (2020) see it as an infectious disease which is caused by severe acute respiratory syndrome coronavirus 2 . Since the outbreak of COVID-19 life has not been the same, it has affected all spheres of life, including the feeding life of people. It has effects on economy, health, society, politics and humanity in the public domain, but how it affects people's feeding (eating) habits and household food security is sparsely known.

Thus, food security, especially at the household level, is simply defined as the availability, accessibility, stability and effective utilisation of food in good nutrients by all household members. A household is more secured, stable and violence-free when food is available and affordable in the right quantity, nutrients and safe to all members (Amusan \& Olawuyi 2019). The reverse is the case when food is in short supply at the household level. According to Roberto et al. (2014), food security includes physical and economic access to food and access to food is one of the pillars of food security. In a more detailed perspective, the Committee on World Food Security (CFS) (2012) adopted the definition of World Food Summit, which sees it as when all persons at all times have unrestricted physical, economic and social access to sufficient, safe and nutritious food that can meet their dietary needs and food preference that can sustain their active and healthy life.

Similarly, the Food and Agriculture Organization of the United Nations (FAO) and Anti-Hunger Programme (AHP) (2004) highlighted the availability, accessibility, utilisation and stability as the core inter-related factors of food security. Given these definitions, household food security connotes the rights of all household members to adequate, safe and nutritious food that can sustain their healthy and active life. Household food security is dependent on the availability, accessibility and affordability of food. The absence of these key pillars (availability, accessibility and affordability) triggers hunger, malnutrition and sometimes violence in the household. Some scientific evidence has attributed the absence of these pillars to climate change (Amusan 2009, Amusan \& Jegede 2014; Camilla 2009; Institute of Development Studies 2014; Mukasa \& Salami 2016; UNDP 2015), natural disasters (Brown, Crawford \& Hammill 2006; Nahusenay 2017) and armed conflicts (Messer \& Cohen 2015).
Thus, the absence of these pillars contributes to household food insecurity that is not only caused by climate change, disasters or crisis but also by pandemics. The coronavirus disease 2019 pandemic has harmed household food security. For instance, the lockdown orders have not only prevented farmers from working on farms but also restricted daily income earners from earning their daily incomes and other business owners from doing businesses.

Consequently, this has heightened hunger, violence and malnutrition at the household level. The WFP (2020) similarly reported that the COVID-19 rapid global spread is threatening to affect millions of people already made vulnerable by food insecurity, malnutrition and the effects of conflict and other disasters. Peterman et al. (2020) also argued that pandemics are closely linked to engagement in negative coping strategies occasioned by household economic insecurity. Low purchasing power or lack of money to buy food is a key component of household economic insecurity coupled with instability in supply because of climatic variables.

Besides the effect of pandemics on food security (Pamela 2020; UN 2020), food insecurity sometimes leads to intrahousehold violence against women and children (Peterman et al. 2020). Specifically, Peterman et al. (2020) and Wanqing (2020) reported that COVID-19 lockdowns have contributed to an increase in the numbers of violence against women and children in the United States of America, Brazil, Australia and China. Households in Africa, including Nigeria, are no exception. According to Peterman et al. (2020), the cause of violence is the fear and uncertainty nature of pandemics. A critical look at Peterman et al.'s (2020) reasons as the cause of violence during pandemics seems not tenable to be the cause of violence amongst African households. In Africa, especially in Nigeria, scientific observations have shown that hunger, lack of palliatives, low purchasing power and inhumane household coping strategies have remained the bane of intrahousehold violence. Evidence shows that women and children are worse hit by intra-household violence during lockdowns occasioned by pandemics.

Lockdown is a policy or an order adopted by governments in different nations to limit the spread of the virus. It is an order that outlawed people from moving out of their homes. It specifically states that every household remains in-door or at home for safety to prevent contact with persons with the virus. Lockdown is interchangeably used for quarantine but the two concepts are not the same, although they serve the same purpose of limiting the spread of the virus. While quarantine is aimed at persons who have come in contact with people who have tested positive for COVID-19 or persons who have travelled to or returned from places with a high incidence of COVID-19. Hitav et al. (2020) similarly shared the view that quarantine is aimed at separation and isolation of individuals who have been in close contact with a positively tested patient. Lockdown is a measure that closes the entire country except essential services such as healthcare service, pharmaceutical service and security services, amongst others. 
The escalation of the virus into a pandemic and its rapid spread made many countries adopt the lockdown, which most people see as draconian and dangerous to human psychological well-being, but had been very successful in slowing down the spread of the virus. For instance, Buja et al. (2020) revealed that although the total lockdown of Italy was perceived by the population as draconian, it actually helped prevent the spread of the virus to other parts of the country. Similarly, Mishra et al. (2020) found that the lockdown in India assisted in flattening the COVID-19 curve, bidding more time for healthcare preparedness, weaving optimism around changing weather conditions and developing a (questionable) herd immunity leveraging their demographic structure as a young population. Conversely, Hitav et al. (2020) revealed that lockdown has subjected Indians to boredom, loss of income, loss of employment and certain rumours related to the condition.

Available evidence shows that lockdown has led to psychological disturbances, ranging from suicides to depression, which has led to broken marriages and homes and stress disorders (Hitav et al. 2020).

Buttressing the negative effects of the lockdown, Oke (2020) noted that locking down people in the Nigerian case is like pushing them into hunger and pangs of hunger will lead to anger. Specifically, it has led to protests at the community level and intra-household violence against women and children. This is because the lockdown order was haphazardly copied and announced for implementation without a comprehensive plan for palliatives in Nigeria. Thus, the COVID-19 pandemic, which has necessitated the lockdown order, has not only pushed people into hunger, but also made them, especially those who live on daily income, to see violence as the only means of surviving or coping during the lockdown.

From the above reviews, it was identified that most studies on COVID-19 were focused on its effect on a country's economy, and only little are focused on food security, and even those that probed food security looked at it from the entire country perspective and not at the household level. This study bridges this gap by examining the implication of COVID-19 for household food insecurity. The study found from the reviews that, indeed, lockdown even though slows down the spread of the virus, it escalates household food crisis. The crisis ranges from hunger (occasioned by inability to access food and inability to afford high price of food), malnutrition (caused by eating of low-nutrient food because of low purchasing power to buy high-nutrient food) and violence (triggered by boredom, psychological trauma, financial stress, loss of job and sexual denial, amongst others) in some developing countries, including Nigeria.

\section{Theoretical underpinning of the coronavirus disease 2019 in Nigeria: Input-output system theory}

The fight against COVID-19 pandemic in Nigeria is better explained with the input-output system theory espoused by
Easton (1965). This theory holds the view that the political system, which is the basic unit of analysis, is a system of interactions in any society through which binding and authoritative allocations of values are implemented (Oke 2020). For instance, a Nigerian system is a political system that takes or makes binding decisions including orders that are implemented and obeyed within the Nigerian society. The political system, which literally means the Nigerian system, through the input segment receives or takes demand and support from the environment (Okaisabor 2021).

It is imperative to note that every environment, including the Nigerians, makes demand on the political system (Yagboyaju \& Akinola 2019). For instance, for the case at hand, people within the Nigerian environment continually face COVID-19 threats (death, fear, spread of infections, sickness, etc.). Subsequently, this threat makes them (Nigerians) place a demand on the government seeking for an end to the spread of the virus within the environment (Nigeria Centre for Disease Control. [NCDC] 2020). The government, a key actor of the political system, receives and normally treats the demand fed into the system as a problem requiring an action or response, which is usually in the form of policy or order at the output segment a problem requiring action or response (Yagboyaju \& Akinola 2019). The Nigerian people have continually made demand on the political system by reporting it as a problem affecting them in their environment (Akinola 2011). For instance, through the National Centre for Diseases and Control (NCDC) many Nigerians have reported cases of suspected COVID-19 as a problem, while others have willingly presented themselves for a test and self-isolate or quarantine (NCDC 2020). The Nigerian government having received the problem through different channels (such as phone calls, self-reporting, state government, NCDC officials, etc.) engages all stakeholders (members of COVID-19 Presidential Task Force, Director of NCDC, Minister of Health, Finance, Humanitarian services, Information and others). The essence is to review, discuss and harmonise views, experiences and interventions to address the threats posed by the virus. This is in a bid that more lives will be saved and the spread of the virus will be curtailed (Ozili 2020). The foregoing stage represents the 'conversion box'. This is the stage where problems are worked on to arrive at possible outcomes or decisions or policy that would largely help to address the problem fed into the system through the input stage. For instance, at the conversion box, the COVID-19 problem is being discussed on a daily basis by the Nigerian political system through the Presidential Task Force, which provides updates on the pandemic in Nigeria (Presidential Task Force [PTF] 2020).

The third segment, which is the output, is the response or action taken to control coronavirus in Nigeria. These include lockdown, social distancing and distribution of palliatives. The feedback segment is the segment mainly used by the people to establish how successful is the action and/or response taken to address the problem. Available evidence from observations showed mixed reactions or feedbacks. For instance, while, on one hand, the lockdown has slowed down the spread of the virus and this has made many Nigerians to 
support government's lockdown order, report cases of suspected carriers of the virus raise alarm against activities of thugs in the neighbourhood (Okaisabor 2021). On the other hand, it has pushed more Nigerians into hunger, violence and psychological disorder. This has been the bane for protests and armed robbery in some parts of the country, especially in Lagos State (Okon 2020).

From the input-output system analysis (see Figure 1), it can be deduced that the theory has four segments, namely, the INPUT (which is the device through which people within the environment place demand [COVID-19 problem] on the political system via various channels [e.g. phone calls, NCDC officials, self-reporting, state government, medical experts, Ministry of Health, etc.]; the CONVERSION BOX segment (at this segment, relevant stakeholders extensively work or debate or discuss or harmonise the problem COVID-19 - for singular purpose of action or response to be adopted or implemented); the OUTPUT segment (this is announcement stage of actions and/or response adopted to tackle the pandemic; in the case of Nigeria, lockdown and palliatives represent an affirmative action or response against the spread of the disease); and the FEEDBACK stage (this is the evaluation stage, where people assess or put to test the action and/or response against COVID-19 in order to provide positive or negative support). Positive feedback is usually in the form of support for continuation of action and/or response against the epidemic, while the negative feedback is followed by protest, violence and resistance to government order (Okon 2020). Ezeibe et al. (2020) specifically noted that the distrust of government policies and actions contributes to the spread of the virus.

The applicability of the theory to the subject matter using concrete example of the looting of the COVID-19 palliatives stored in some warehouse across the country is a negative reaction to policy of lockdown that tends to restrict movement of people without any adequate and meaningful plan or strategy to relax the harsh effect of such policy. For instance, the lockdown order by the Nigerian government is a policy or action reached or agreed after a thorough analysis and harmonisation of various problems and alternatives opened to government in its quest to flatten the spread of the virus. In

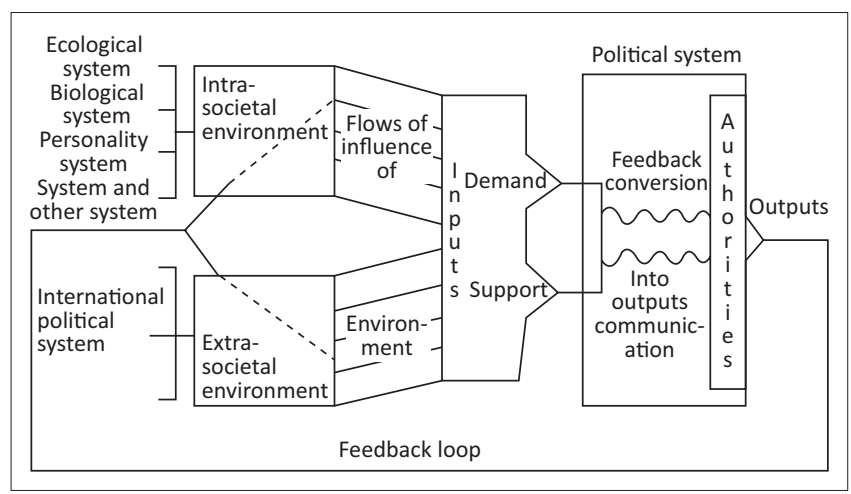

Source: Adapted from Easton, D., 1965, A systems analysis of political life, John Wiley \& Son Inc., New York, NY.

FIGURE 1: Dynamic model of Easton's political system. the Nigerian case, this policy generated both negative and positive feedback.

The positive feedback is evident in low or minimal compliance with COVID-19 safety (wearing of face masks, social distancing and remaining at home during lockdown, amongst others) protocols. For example, few Nigerians, especially the civil servants, complied with the lockdown policy. This could have been possible because of the government circulars or notices stipulating that certain categories of workers should work from home (Okaisabor 2021). Similarly, from the positive feedback perspective, few Nigerians abide by government regulations on curfews, wearing of face masks and social distancing as well as assisted in contact tracing of suspected carriers of the virus (Adedigba 2020). From the negative feedback perspective, the lockdown provoked nationwide protests, disobedient to government's rules on curfews or social distancing. Evidence shows that many churches and other worshipping centres disobeyed the lockdown policy (Jimoh \& Akor 2020; Okaisabor 2021).

The extra-judicial killings (Olaiya 2020) and looting of warehouses in custody of COVID-19 palliatives containing household food items by mainly the Nigerian youths are negative feedback of the lockdown policy (Okon 2020). The growing suspicion that the food items were reserved to be shared during election or for party members and lack of adequate information from the government about the palliatives provoked the youth leading to criminal looting of warehouses across the country (Ajayi 2020; NAN 2020). Similarly, Ezeibe et al. (2020) opined that the growing distrust of reports or daily COVID-19 update or briefing is a good example of negative feedback against government's action or policy on COVID-19.

Having examined the input-output theory, this article intends to discuss how households are affected by total lockdown in Nigeria - the area of focus of this article.

\section{The coronavirus disease 2019 pandemic and the crisis of lockdowns in Nigeria: The case of household food security}

The coronavirus disease 2019 novel pandemic undoubtedly has put more pressure on governments, people and countries of the world. Specifically, its effects on the economy, psychological well-being, health, businesses, education, and global power tussle have continued to earn research attentions around the world. For instance, studies have been conducted on its effects on mental health (Huang et al. 2020; Sijia et al. 2020), global economy (Elliot 2020; Horowit 2020; Ozili \& Arun 2020), education (UNESCO 2020), businesses (El-Erian 2020) and global power relations (Monish \& Hariharan 2020). However, the full impact of the virus on food security is yet to be known. Food and Agriculture Organization (FAO 2020) attributed the slow 
identification of the impact of the virus on food and agricultural food system to the continued spread of the virus, which has locked down many farmers at home, thus making it very difficult to reach the farmers to ascertain the level of the impact of COVID-19 on food systems. Given this gap, this section examines the connection between the epidemic and expanding crisis of lockdowns and its effect on household food insecurity in Nigeria.

One of the crises of COVID-19 lockdown in Nigeria was panic buying, which in turn led to spike in household food prices. This is well explicated by Gakpo (2020) who stated that the announcement of the lockdown is prompting food insecurity fears in Africa, which has triggered rising prices, panic buying and import-export disruptions. Libby (2020) revealed that COVID-19 lockdown had severely triggered scarcity and high prices of the main staple food beyond the reach of some people. In the same vein, Ojo (2020) noted that food shortages and price shocks for the consumers are key components of the lockdown crisis in Nigeria. All things being equal, spike in food prices reduces the quantity of food at household level, and low quantity of food is a potential threat to households' food security. This is because it limits the availability of food, which is a key component of food security. The foregoing was well captured in WFP (2020) report, which shows that COVID-19 lockdown measure is exacerbating food shortages in Africa.

Similarly, World Bank (2020) report showed that the pandemic is creating tensions for food availability and accessibility in many countries.

Again, scientific observation indicates a shortage in household food within the first week of the lockdown. Thus, findings from this analysis show a strong positive link between COVID-19 and food insecurity as most households face with problems of food availability, affordability and accessibility triggered by spike in food prices. Corroborating this finding was the study of Buja et al. (2020) who reported his personal observation in China; he noted that the lockdown order has had an impact on the circulation, and thus availability, of food and agricultural products, and has also interrupted several value chains, with a potential impact on prices.

This by implication leads to hunger, skipping of food and food shortage at the household level (FAO 2020; Libby 2020; Oke 2020; Okon 2020).

Besides, low purchasing power or lack of money to buy food is another problem caused by COVID-19 lockdown. Lockdowns restrict movement of people to workplaces; this scuttled income generation and pushed many to debt peonage in developing states with emphasis on Nigeria. Many people resort to borrowing to buy food, while others buy on credit to feed household members. This crisis was well documented in the World Bank (2020) report which showed that loss of incomes and remittances aggravate food insecurity risks at household level. The pandemic, according to Onyekwena and Ekeruche (2020), has affected the incomegenerating capacity of households on contract job or daily income earners. This finding is the same with Buja et al. (2020) who found that one of the lockdown crises is restrictive preventive measures, which ultimately affect labour wage and household income. It is imperative to note that there is a strong correlation between COVID-19 and low purchasing power of households, considering the inability of some households to access sufficient, nutritious and safe food.

Another crisis of the lockdowns in Nigeria is the cut in the internal supply of food to the market from the farm. This could be attributed to labour shortage during lockdowns, manifested through restriction of farmers to work on the farms and prevention of truck drivers to convey food from the farm to the market. This was aggravated by the Nigerian Police Force officers' brutality and corruption against Nigerians (Kabir 2020).

Food and Agriculture Organization (FAO 2020) reported that shortage of labour could disrupt production and processing of food, notably for labour-intensive crops. In spite of the fact that food services were exempted from lockdown, internal supply chains of food were still not very active, as evidence shows that the majority of truck drivers are afraid of being arrested or brutalised by the police (Libby 2020). Lockdown measures have disrupted internal supply chains halting food production (World Economic Forum 2020). Furthermore, UN (2020) and World Bank (2020) in a bid to show the effect of COVID-19 disruptions on food security reported that millions of people in sub-Saharan Africa are at risk of not getting the food they need because of coronavirus disruptions. Buja et al. (2020) predicted that continual lockdowns would negatively impact agricultural production, with consequent long-lasting and deeper impacts on food availability, prices and, ultimately, overall food security.

Lockdowns exacerbate the reduction in domestic crops production and capacity for staple foods. With the restriction on movement of people, there is a low turnout of farmers on farms to cultivate lands for cropping. The time of the pandemic coincides with the time of land preparation for planting because of the seasonal rainfall that majority of farmers depend on in the country. Besides, daily labourers who assist farmers in crop production have also been locked down at home as a result of the COVID-19 pandemic; this invariably heightens the low interests of farmers in domestic crop production during lockdowns. As a result of closed borders migrant farm workers from the Republic of Benin and Togo between February and March each year are unable to cross to Nigeria (UNCTAD 2018); this is affecting food supply in the short run and will affect the same in the long run. This disruption in the food supply chain and economic recession are likely to cause havoc in food production and delivery (FAO 2020). Given this premise, World Economic Forum (2020) observes that the COVID-19 pandemic reduces food production and availability, thus leading to household food insecurity. 
The coronavirus disease 2019 lockdown limits the daily earnings of some households, especially those who are on daily income business, job or trade. Limitation in income is a potential source of inability to access food. Accessibility is a key component of food security, and a reduction in the purchasing power of households is a big threat to household food security. The coronavirus disease 2019 lockdowns had been observed and found to be a contributory factor to low disposable household income, especially by households on self-employed jobs, and the poor in government offices (low-rank officials). The foregoing scientific observation is consistent with the prediction of Onyekwena and Ekeruche (2020) that COVID-19 will lead to low household consumption caused by low-income earnings of households on contract or short-term jobs. Available evidence shows that with the absence of government palliatives, the majority of households find it very difficult to purchase food within the first 2 weeks of lockdown.

Also COVID-19 lockdown limits the ability of households to consume nutritious food. It limits consumption expenditure. Many households have to settle down for the purchase of very cheap and low-nutrient foods because the lockdown had severely affected their income earnings; it has led to disruption in nutrition, food aid, school feeding, safety net or social protection and Early Childhood Development services, with high impacts on the vulnerable group (Federal Ministry of Health 2020). Movement restrictions have not only reduced the consumption of non-essential commodities in general, but also affected the income-generating capacity of these groups, thus reducing their consumption expenditure (Onyekwena \& Ekeruche 2020), and restrict people's access to sufficient or diverse nutritious sources of food (Gakpo 2020).

Negative coping strategies such as skipping of food, eating very late, engaging in debt and transactional sex are known crises associated with COVID-19 lockdown. Skipping of food and eating very late are popular strategies adopted by most vulnerable households who do not have enough money to buy food. The poor vulnerable households are the worse hit by COVID-19 pandemic. It is an established and proven fact that most vulnerable households engage in transactional sex and debt to buy food, which is ongoing in many African states and will continue as long as lockdowns are there. Unless meaningful palliative measures are in place, both girls and housewives who have turned to be breadwinners will exchange sex for financial reward so as to put food on tables (Van der Heijden \& Swart 2014). The long-term effects of this are unwanted children and further spread of HIV and AIDS in the country that is economically battling for its soul in the world of drastic drop in the global price of crude oil, which is the main source of foreign exchange in Nigeria. This is consistent with the report of Adedayo (2020), in cable lifestyle, who reveals how a popular musician in Nigeria, Don Jazzy, gave the sum of N100 $000^{1}$ to an elderly woman who openly begged to offer her body to anyone for sex at a cost of five hundred naira (N500) in a bid to buy food to eat and feed her kids.

1.At the time of this research article, the exchange rate was N22 to $\mathrm{R} 1$.
Violence, especially the one against women and children, is potential fallout of the lockdown order in Nigeria. A significant number of husbands whose means of livelihood have been cut by the lockdown are psychologically disturbed, socially incompetent and made to bullying. Added to this is the lack of palliatives from the government to ease the effects of lockdown. The Nigerian government only copied the lockdown policy from Europe and the United States of America, without any viable and sufficient plan for palliatives to people. Lockdown without palliatives and means of livelihood provokes the feelings of economic insecurity in African men, who always want to be in effective control of their homes. Money is one of the tools that African men, especially Nigerian men, use in the control of their homes. Financial stability or capability of household heads, especially the men, reduces intra-family tensions, conflicts and violence. However, empirical research has shown that economic insecurity (especially the ones triggered by lockdown, quarantine, self-isolation and social distancing) is the cause of violence against women and children in many homes during the outbreak of pandemics and public health emergencies (Brand et al. 2013; Lau et al. 2005; Mak et al. 2009; Yeung \& Fung 2007). Thus, economic stress is linked to intra-familial violence (Fox et al. 2002; Renzetti 2009).

Similarly, Wenham, Smith and Morgan (2020) predicted that women and children will be worse hit by COVID-19 lockdowns, just like other pandemics such as Ebola and SARS.

\section{Conclusion and recommendations}

Based on the theoretical adventure into David Easton's inputoutput approach, findings from the foregoing analysis showed that the outbreak of the novel virus (COVID-19) pushed governments of different countries, including Nigeria, to implement specific safety measures (such as lockdowns, selfisolation or quarantine and social distancing). Evidence shows that these measures, especially the lockdown order, exacerbate crises that have, and can, hurt household food security. The coronavirus disease 2019 lockdown is a threat to all the core segments of food security (availability, accessibility, affordability, stability and utility). Empirical research showed that lockdown and restriction of movement obstruct internal supply of food and domestic production (food availability). Thus, a break in the chain of internal food supply and low domestic crop production affect food availability. Similarly, the study found that COVID-19 lockdowns affect accessibility of food. Evidence discussed above indicates that lockdowns reduced not only the purchasing power of some households, but also led to loss of income source. This affects the second and third core segments (accessibility and affordability) of food security. This study's findings on access to, and utilisation of, nutritious food are particularly more revealing. Empirical findings show that the spike in food prices because of panic buying and limits in the supply of food items, loss of income source or rapid decline in purchasing power stimulate many households to buy low-nutrient food. The article also notes that most school children, especially those from vulnerable 
households, were denied access to nutritious food of the school feeding programme in Nigeria. This shows that COVID-19 lockdowns limit access to nutritious food, which is a key component of food security.

Malnutrition, especially amongst children, has implication for food (in)security, and this has implication on the spread of COVID-19 in Nigeria. For instance, records have shown that hungry-looking and undernourished Almajiri ${ }^{2}$ children who were ejected in Kano State are carriers of the deadly virus (COVID-19) in northern Nigeria. The understanding of the fact that the lockdown policy aggravates hunger, violence, low purchasing power and shortage of food can motivate the Nigerian government to provide adequate palliatives for the people. It is absolutely unfair and totally unacceptable to lock down people at home without palliatives. The Nigerian government has been very insensitive to the plight of people during lockdowns. Promises have been made by the government to provide palliatives, but it is yet to be fulfilled or implemented, and many vulnerable people still languish in pain inflicted on them by the lockdown. At best, palliative measures embarked by government turned out to be politically motivated as only party members benefitted from unsustainable meagre food distributed by party leaders amongst members.

In view of the above findings, it is strongly suggested that the government, specifically local governments that are closer to the people, should design an all-encompassing palliative care policy to cover vulnerable Nigerians, especially those on contract job, self-employment, or poor income earners in both private and public offices. Similarly, senators, members of the parliament and wealthy Nigerians should complement the efforts of government in the provision of palliatives to people in their constituency. Besides, the police should be properly monitored and put to check against illegal collection of money from violators of the lockdowns. This will help to check and control the spread of the virus. There should be continual orientation and awareness programmes to teach and educate people about precautions against COVID-19 spread. More importantly, there should be support in the form of an improved budgetary allocation to agricultural sector to assist in research, extension services, food production and nutrition adequacy; this will promote food security in the post-COVID-19 period. There is a need to plan for adequate food production after the COVID-19 pandemic through stimulus packages from the Ministry of Agriculture at national and state levels.

\section{Acknowledgements}

The authors are grateful to the anonymous fellows who assisted in the pilot study of this article.

\section{Competing interests}

The authors declare that no competing interests exist.

2.These are children who are sent to Arabic school in the northern part of the country without western education. They are always fend for themselves and the teachers in their school through begging on the street. For more information on this, see Nwanze (2019).

\section{Authors' contributions}

L.A. and S.C.A. authors contributed equally to this work.

\section{Ethical considerations}

This article followed all ethical standards for carrying out research while developing and finalised the article.

\section{Funding information}

This research received no specific grant from any funding agency in the public, commercial or not-for-profit sectors.

\section{Data availability}

The authors confirm that the data supporting the findings of this study are available within the article.

\section{Disclaimer}

The views and opinions expressed in this article are those of the authors and do not necessarily reflect the official policy or position of any affiliated agency of the authors.

\section{References}

Adedayo, A.R., 2020, Don Jazzy gifts N100k to elderly woman who offered sex for N50O, 11 April, viewed 24 June 2020, from https://lifestyle.thecable.ng/donjazzy-gifts-n100k-to-elderly-woman-who-offered-sex-for-n500/.

Adedigba, A., 2020, 'Coronavirus: Nigerian government orders closure of schools nationwide', Premium Times, 19 March, viewed 20 April 2021, from https://www. premiumtimesng.com/news/top-news/382806-coronavirus-nigerian-govtorders-closure-of-schools-nationwide.html.

Ajayi, O., 2020, 'FG to Nigerians: We would have flattened Covid-19 curve but for your nonchalance', Vanguard, 21 August, viewed 20 April 2021, from https://www. vanguardngr.com/2020/08/fg-to-nigerians-we-would-have-flattened-covid-19curve-but-for-your-nonchalance/.

Akinola, A.O., 2011, 'Niger delta crisis: The Nexus between militants' insurgency and security in West Africa', Africa Security 4(1), 46-61. https://doi.org/10.1080/1939 2206.2011.563180

Amusan, L., 2009, Africa and climate change in the era of complex interdependent globalized International system, viewed 20 April 2021, from https://www. academia.edu/8076518/Africa_and_Climate_Change_in_the_Era_of_Complex_ Interdependent_Globalised_International_System.

Amusan, L. \& Jegede, A.O., 2014, 'Adaptation in an era of vanishing territory - The political economy of the impact of climate change versus total migration, status of statehood and refugees in Africa', Environmental Economics 5(2), 99-106.

Amusan, L. \& Olawuyi, S.O., 2019, 'Between food quality and quantity for all in Africa: What they refuse to tell us about GMO', Gender \& Behaviour 17(1), 12284-12298.

Berger, Z.D., Nicholas, G.E., Alexandra, L.P. \& Ross, D.S., 2020, 'Covid-19: Control measures must be equitable and inclusive', BMJ Editorials 368, m1141. https:// doi.org/10.1136/bmj.m1141

Brand, J., McKay, D., Wheaton, M.G. \& Abramowitz, J.S., 2013, 'The relationship between obsessive compulsive beliefs and symptoms, anxiety and disgust sensitivity, and swine flu fears', Journal of Obsessive-Compulsive and Related Disorders 2, 200-206.https://doi.org/10.1016/j.jocrd.2013.01.007

Brown, O., Crawford, A. \& Hammill, A., 2006, Natural disasters and resource rights: Building resilience, rebuilding lives, International Institute for Sustainable Development, Winnipeg.

Buja, A., Paganini, M., Cocchio, S., Scioni, M., Rebba, V. \& Baldo, V., 2020, 'Demographic and socio-economic factors, and healthcare resource indicators associated with the rapid spread of Covid-19 in Northern Italy: An ecological study', PLOS ONE 15(12), e0244535. https://doi.org/10.1371/journal.pone.0244535

Camilla, T., 2009, Climate change in Africa, Zed Books, London.

Committee on World Food Security (CFS), 2012, 'Coming to terms with terminology: Food security, nutrition security, food security and nutrition, food and Food security, nutrition security, food security and nutrition, food and Rome, 15-20 October, viewed 20 April 2021, from http://www.fao.org/3/ MD776E/MD776E.pdf.

Devereux, S., 2018, 'Food insecurity and femine', in T. Binns, K. Lynch \& E. Nel (eds.), The Routledge handbook of African development, pp. 183-201, Routledge, London.

Doyle, J.J. \& Aizer, A., 2018, 'Economics of child protection: Maltreatment, foster care and intimate partner violence', The Annual Review of Economics 10, 87-108. https://doi.org/10.1146/annurev-economics-080217-053237

Easton, D., 1965, A systems analysis of political life, John Wiley \& Sons Inc., New York, NY. 
Eichenbaum, M.S., Rebelo, S. \& Trabandt, M., 2020, The macroeconomics of the epidemics, CEPR working paper DP1452, National Bureau of Economic Research, Cambridge, viewed 20 April 2021, from https://www.nber.org/system/files/ Cambridge, viewed 20 April 2021,
working_papers/w26882/w26882.pdf.

El-Erian, M.A., 2020, How to rebuild from the shock of Covid-19, International Financial Cooperation Insight, viewed 20 April 2021, from https://www.ifc.org/wps/wcm/ connect/news_ext_content/ifc_external_corporate_site/news+and+events/n.

Elliot, L., 2020, 'Prepare for the coronavirus global recession', The Guardian, Media report, viewed 24 April 2020, from https://www.theguardian.com/business/2020/ mar/15/prepare-for-the-Coronavirus-Global-Recession.

Ezeibe, C.C., Ilo, C., Ezeibe, E.N., Oguonu, C.N., Nwankwo, N.A., Ajaero, C.K. et al., 2020, 'Political distrust and the spread of Covid-19 in Nigeria', Global Public Health 15(12), 1753-1766. https://doi.org/10.1080/17441692.2020.1828987

Food and Agriculture Organization of the United Nations (FAO) \& Anti-Hunger Programme (AHP), 2004, Anti-hunger programme: Reducing hunger through agriculture and rural development and wider access to food, Food and Agriculture Organization of the United Nations, Rome.

Food and Agriculture Organization of the United Nations (FAO), 2011, The state of food and agriculture 2010-2011: Women in agriculture: Closing the gender gap for development, FAO, Rome, viewed 13 May 2020, from www.fao.org/ docrep/013/i2050e/i2050e.pdf.

Food and Agriculture Organization of the United Nations (FAO), 2020, Addressing the impacts of Covid-19 in food crises / April-December 2020: FAO's component of the
global Covid-19 humanitarian response plan, Rome, viewed 13 May 2020, from global Covid-19 humanitarian resp
https://doi.org/10.4060/ca8497en

Federal Ministry of Health, 2020, 'Coronavirus - Nigeria: Health Minister urges extra vigilance with easing of Covid-19 lockdown, Africanews, viewed 20 April 2021 from https://www.africanews.com/2020/05/05/coronavirus-nigeria-healthfrom https://www.africanews.com/2020/05/05/coronavirus-n
minister-urges-extra-vigilance-with-easing-of-covid-19-lockdown/.

Fox, G.L., Benson, M.L., De Maris, A.A. \& Wyk, J.V., 2002, 'Economic distress and intimate violence: Testing family stress and resources theories', Journal of Marriage and Family 64(3), 793-807. https://doi.org/10.1111/j.1741-3737. 2002.00793.x

Gakpo, J.O., 2020, Covid-19 virus spread prompts food insecurity fears in Africa, 26 March, viewed 14 April 2020, from https://allianceforscience.cornell.edu/ blog/2020/03/covid-19-virus-spread-prompts-food-insecurity-fears-in-africa/.

Guterres, A., 2020, Secretary-General: Africa's response to Covid-19 pandemic has provided valuable lessons for the rest of the world, United Nations: Africa Renewal, viewed 20 April 2021, from https://www.un.org/africarenewal/news/ coronavirus/secretary-generals-op-ed-policy-brief-impact-covid-19-africa.

Guterres, A., 2020, Africa's response to Covid-19 pandemic has provided valuable lessons for the rest of the world, United Nations Africa Renewal.

Hamza, M., 2020, 'Coronavirus pandemic', Al Jazeera, Published 19 March 2020, viewed 12 May 2020, from https://www.aljazeera.com/news/2020/03/coronaviruspandemic-experts-somalia-risk-greater-china-200319052938789.html.

Heath, K., 2011, 'The classical definition of a pandemic is not elusive', Bulletin of the World Health Organization 89, 540-541. https://doi.org/10.2471/BLT.11.088815

Hitav, S., Prachi, S., Swara, D., Priya, G., Janvi, S., Priti, M. et al., 2020, 'Does social distancing during the lockdown due to Covid-19 outbreak affect quality of life?', International Journal of Clinical and Biomedical Research 6(2), 1-4. https://doi. International Journal of Clinical
org/10.31878/ijcbr.2020.62.01

Horowit, J., 2020, 'The global coronavirus recession is beginning', CNN, Media report, viewed 24 June 2020, from https://edition.cnn.com/2020/03/16/economy/ global-recession-coronavirus/index.html.

Huang, R., Zhu, L., Xue, L., Liu, L., Yan, X., Wang, J. et al., 2020, 'Clinical findings of patients with coronavirus disease 2019 in Jiangsu province, China: A retrospective, multi-centre study', PLOS Neglected Tropical Diseases 14(5), e0008280. https:// doi.org/10.1371/journal.pntd.0008280

Institute of Development Studies, 2014, The hunger and nutrition commitment index Measuring the political commitment to reduce hunger and under-nutrition in developing countries, IDS, Brighton.

Jimoh, A. \& Akor, O., 2020, 'Nigeria: Covid-19 - Our self-isolation policy has failed FG', A buja: Daily Trust, 08 May, viewed 20 April 2021, from https://dailytrust.com/ covid-19-our-self-isolation-policy-has-failed-fg.

Kabir, A., 2020, 'Lockdown: Police officers caught on camera assaulting woman', Premium Times, 19 April, viewed 28 June 2020, from https://www. premiumtimesng.com/news/more-news/388697-lockdown-police-officerscaught-on-camera-assaulting-woman.html.

Laetitia, B., 2020, 'Millions of Ethiopians can't get Covid-19 news', Human Rights Watch, 20 March, 2020, viewed 28 June 2020, from https://www.hrw.org/ Watch, 20 March, 2020, viewed 28 June 2020, from http
news/2020/03/20/millions-ethiopians-cant-get-covid-19-news.

Lattouf, A., 2020, Domestic violence spikes during coronavirus as families trapped at home, viewed 28 April 2020, from https://10daily.com.au/news/australia/ a200326zyjkh/domestic-violence-spikes-uringcoronavirus-as-families-trapped-athome-20200327.

Lau, J.T.F., Yang, X., Pang, E., Tsui, H.Y., Wong, E. \& Wing, Y.K., 2005, 'SARS-related perceptions in Hong Kong', Emerging Infectious Diseases 11(3), 417-424.

Laura, H., 2020, Let's talk about Covid-19 and Diversity \& Inclusion, viewed 20 April 2021 , from https://home.kpmg/xx/en/blogs/home/posts/2020/05/covid-19and-diversity-and-inclusion.html.

Libby, G., 2020, Covid-19 is exacerbating food shortages in Africa, viewed 20 April 2021, from https://hungrycities.net/covid-19-is-exacerbating-food-shortages-in-africa/.

Mak, I.W.C., Chu, C.M., Pan, P.C., You, M.G.C. \& Chan, V.L., 2009, 'Long-term psychiatric morbidities among SARS survivors', General Hospital Psychiatry 31(4), 318-326. https://doi.org/10.1016/j.genhosppsych.2009.03.001
Messer, E. \& Cohen, M.J., 2015, 'Breaking the links between conflict and hunger Redux', World Medical and Health Policy 7(3), 211-233. https://doi.org/10.1002/ wmh3.147

Mishra, S., Mohapatra, A., Kumar, R., Singh, A., Bhadoria, A.S. \& Kant, R., 2020, 'Restricting rural-urban connect to combat infectious disease epidemic as India fights Covid-19', Journal of Family Medicine and Primary Care 9(4), 1792-1794. https://doi.org/10.4103/jfmpc.jfmpc_451_20

Monish, T. \& Hariharan, H., 2020, 'Covid-19 will make the US-China great power dynamics more confrontational', The Diplomat, 15 April, viewed 21 June 2020 from https://thediplomat.com/2020/04/covid-19-will-make-the-u-s-china-greatpower-dynamics-more-confrontational/.

Morens, D.M., Folkers, G.K. \& Fauci, A.S., 2009, 'What is a pandemic?', The Journal of Infectious Diseases 200, 1018-1021. https://doi.org/10.1086/644537

Mukasa, A. \& Salami, A., 2016, 'Gender equality in agriculture: What are really the benefits for sub-Saharan Africa?', Chief Economist Complex / AEB 7(3), 1-12.

Nahusenay, A., 2017, 'The roles of rural women on agricultural labor conscriptions in Ethiopia: The case of Delanta district, South Wello Zone', EC Nutrition 6.4 (2017), 144-155, viewed 20 April 2021, from https://www.ecronicon.com/ecnu/pdf/ ECNU-06-0000203.pdf.

Narendra, K.B., Saurabh, S. \& Arun, G., 2020, 'A study on impact of Covid-19: A global pandemic on Indian economy with special context to goods and service tax', Journal of Xidian University 14(3), 1809-1818.

National Domestic Violence Hotline, 2020, Staying safe during Covid-19, viewed 17 March 2020, from https://www.thehotline.org/2020/03/13/staying-safe-during-covid-19/.

Nigeria Centre for Disease Control (NCDC), 2020, Public health advisory to Nigerians on coronavirus disease, Weekly Epidemiological Report, viewed 17 March 2020, from www.ncdc.gov.ng.

News Agency of Nigeria (NAN), 2020, 'Covid-19: PTF decries poor level of compliance with safety measures', 15 June, viewed 20 April 2021, from https://nnn.ng/covid19-ptf-decries-poor-level-of-compliance-with-safety-measures/.

Nwanze, C., 2019, 'History of the Almajiri system in Nigeria', The Guardian, 29 May, viewed 01 June 2020, from https://guardian.ng/features/history-of-the-almajirisystem-in-nigeria/.

Ojo, M., 2020, 'Covid-19 and our food systems - How Nigerian SMEs in food and nutrition can adapt and respond', Business Day, 23 April, viewed 01 June 2020, from https://businessday.ng/opinion/article/covid-19-and-our-food-systemshow-nigerian-smes-in-food-and-nutrition-can-adapt-and-respond/.

Okaisabor, J.O., 2021, 'Public policies against Covid-19 pandemic in Nigeria: Challenges, effects, and perceptions', Journal of Public Administration and Socia Welfare Research 6(1), 16-28.

Oke, O., 2020, 'The impact on Nigeria of the coronavirus pandemic: Socioeconomic pandemonium', The Marxism, viewed 01 June 2020, from https://www.marxist. com/the-impact-on-nigeria-of-the-coronavirus-pandemic-socioeconomicpandemonium.html.

Okon, D., 2020, 'Lamentation still trails Lagos, FG's palliative package as middlemen hijack programme', Business Day, 19 April, viewed 20 April 2021, from https:// businessday.ng/features/article/lamentation-still-trails-lagos-fgs-palliativebusinessday.ng/features/article/lamentatior
package-as-middlemen-hijack-programme/.

Olaiya, T.T., 2020, 'NHR condemns rising killings, rights violation during lockdown extension', The Guardian, 12 May, viewed 20 April 2021, from https:/guardian. ng/news/nhrc-condemns-rising-killings-rights-violation-during-lockdownextension/.

Onyekwena, C. \& Ekeruche, A.M., 2020, Understanding the impact of the Covid-19 outbreak on the Nigerian economy, Brookings Institute.

Ozili, P.K., 2020, 'Covid-19 pandemic and economic crisis: The Nigerian experience and structural causes', SSRN Electronic Journal 21(4), 1-29. https://doi.org/ $10.2139 / \mathrm{ssrn} .3567419$

Ozili, P.K. \& Arun, T., 2020, 'Spillover of Covid-19: Impact on the global economy', 27 March, viewed 01 June 2020, from https://ssrn.com/abstract=3562570.

Pamela, C.H., 2020, 'Covid-19 and food security in vulnerable countries', in United Nations conference on trade and development, pp. 1-6. United Nations, Geneva.

Peterman, A., Potts, A., Megan, O., Thompson, K., Shah, N., Oertelt-Prigione, S. et al., 2020, 'Pandemics and violence against women and children', CGD working paper 528, Center for Global Development, Washington, DC, viewed 01 June 2020, from https://www.cgdev.org/publication/pandemics-and-violence-against-womenhttps://www.cs

Pereira, A., Peterman, A., Neijhoft, A., Buluma, R., Kaloga, I.F., Harvey, R. et al., 2020 'Disclosure and help-seeking behavior among child victims of physical and sexual violence: A cross-country analysis from six countries', Working paper, pp. 1-23. violence: A cross-count
Springer, California.

Piguillem, F. \& Shi, L., 2020, 'Optimal Covid-19 quarantine and testing policies', April, Centre for Economic Policy Research discussion paper no. DP14613, viewed 03 June 2020, from https://ssrn.com/abstract $=3594243$.

Porta M. (ed.), 2014, 'A dictionary of Epidemiology', 6th edn., Oxford University Press, Oxford

Presidential Task Force (PTF), 2020, Daily updates on Covid-19 virus in Nigeria, viewed n.d., from http://statehouse.gov.ng/covid19/.

Renzetti, C.M., 2009, Economic stress and domestic violence, VAWnet, Harrisburg, PA, A project of the National Resource Center on domestic violence/Pennsylvania coalition against domestic violence, viewed 01 June 2020, from http://www.vawnet.org.

Roberto, C., Hamid, E., Philipp, D., Gianluigi, C. \& Noureddin, D., 2014, 'Food economic accessibility and affordability in the Mediterranean region: An exploratory assessment at micro and macro levels', Journal of Food Security 2(1), 1-12. https://doi.org/10.12691/jfs-2-1-1 
Rothan, H.A. \& Byrareddy, S.N., 2020, 'The epidemiology and pathogenesis of coronavirus disease (Covid-19) outbreak', Journal of Autoimmunity 109, 102433. https://doi.org/10.1016/j.jaut.2020.102433

Sijia, T., Nan, H., Jing, L., Shengmei, N., Luxi, Z. \& Jinjun, Z., 2020, 'Characteristics of Covid-19 infection in Beijing', Journal of Infection 80(4), 401-406. https://doi. org/10.1016/j.jinf.2020.02.018

Stiglitz, J., 2002, Globalization and its discontents, Penguin Books, London.

Tallack, B., Mitchell, G.E., Schmitz, H.P. \& Bruno-van Vijfeijken, T., 2020, Covid-19 and the urgency of long-term strategy, InterAction Working Paper, viewed 20 April 2021, from https://www.interaction.org/blog/covid-19-and-the-urgency-of-longterm-strategy/.

United Nations Coordinated Appeal, 2020, 'Global humanitarian response plan Covid-19', A working paper of the Office for the Coordination of Humanitarian Affairs (OCHA), Geneva, viewed 20 April 2021, from https://www.un.org/ development/desa/ageing/wp-content/uploads/sites/24/2020/05/GHRPCOVID19_May_Update.pdf.

United Nations Conference on Trade and Development (UNCTAD), 2018, Economic development in Africa Report 2018: Migration for structural transformation, UN Publications, New York, NY.

United Nations Development Programme (UNDP), 2015, Becoming the zero hunger generation: Achieving food security for all, Annual Report, viewed 20 April 2021 from http://www.fao.org/3/i4951e/i4951e.pdf.

United Nations Educational, Scientific and Cultural Organization (UNESCO), 2020, Covid-19 and children education: A cross-case analysis of nine experiences, UNIOESCO, Paris.

United Nations High Commissioner for Refugees (UNHCR), 2020, UN volunteer supports UNHCR with Covid-19 response in Chad, viewed 20 April 021, from https://www.unv.org/Success-stories/UN-Volunteer-supports-UNHCR-Covid-19response-Chad.

United Nations, 2020, Covid-19: Our hungriest, most vulnerable communities face 'a crisis within a crisis', viewed n.d., from https://www.un.org/africarenewal/news/ coronavirus/covid-19-our-hungriest-most-vulnerable-communities-face-\%E2\% 80\%9C-crisis-within-crisis\%E2\%80\%9D.
United Nations Standing System Committee on Nutrition (UNSCN), 2020, The Covid-19 pandemic is disrupting people's food environments: A resource list on food systems and nutrition responses, viewed 23 June 2020, from https:// www.unscn.org/uploads/web/file/Covid-19-Nutrition-Resources-UNSCN200420.pdf.

Van der Heijden, I. \& Swart, S., 2014, “'Something for something": The importance of talking about transactional sex with youth in South Africa using a resilience-based approach', Journal of AIDS Research 13(1), 53-63. https://doi.org/10.2989/16085 906.2014.886602

Wanqing, Z., 2020, Domestic violence cases surge during Covid-19 epidemic, viewed 28 March 2020, from https://www.sixthtone.com/news/1005253/domesticviolence-cases-surge-during-covid-19-epidemic.

Wenham, C., Smith, J. \& Morgan, R., 2020, 'Covid-19: The gendered impacts of the outbreak', The Lancet 395(10227), 845-848. https://doi.org/10.1016/S01406736(20)30526-2

World Food Programme (WFP), 2020, Supporting children's well-being during the Covid-19 pandemic, viewed 21 June 2020, from https://www.wfp.org/ publications/supporting-childrens-well-being-during-covid-19-pandemic.

World Health Organization (WHO), 2010, What is a pandemic?, WHO, 24 February, viewed 01 May 2020, from http://www.who.int/csr/disease/swineflu/frequently asked_questions/pandemic/en/.

World Health Organization (WHO), 2020, 'Disease outbreak news 234 update - 12 January', Novel coronavirus - China, viewed 12 April 2020, from https://www. who.int/csr/don/12-january-2020-novel-coronavirus-china/en/.

World Bank, 2020, Most commodity prices to drop in 2020 as coronavirus depresses demand and disrupts dupply, 23 April, The World Bank Report, Washington, DC.

World Economic Forum, 2020, How a post-Covid-19 revival could kick-start Africa's free trade area, 29 May, The World Economic Forum Covid Action Platform.

Yagboyaju, D.A. \& Akinola, A.O., 2019, 'Nigerian state and the crisis of governance: A critical exposition', Sage Open 9(3), 1-10. https://doi.org/10.1177/2158244019865810

Yeung, D.Y.L. \& Fung, H.H., 2007, 'Age difference in coping and emotional responses towards SARS: A longitudinal study of Hong Kong Chinese', Aging and Mental Health 11(5), 579-587. https://doi.org/10.1080/13607860601086355 